\title{
Book Review Essay
}

\section{Lawyers, Corporations and Knowledge}

LAwYERS IN SOCIETY. By Richard L. Abel and Philip S.C. Lewis, 3 vols. Berkeley: University of California Press 1988. Pp. 1413. The Legal Profession In England and Wales. By Richard L. Abel. Oxford: Basil Blackwell 1988. Pp. 548.

\section{Reviewed by Martin Shapiro*}

Richard Abel and Phillip Lewis have led an enormous enterprise in the sociology of the legal profession that has produced Lawyers in Society, comprised of three volumes: one consisting of individual studies of common law countries, one of civil and one of comparative studies. In total there are thirty-one contributions by thirty-four authors. In addition, Abel has produced whole volumes on Great Britain and the United States that are extensions of the studies of these two nations that he prepared for the three volume set. One of these, The Legal Profession in England and Wales, is reviewed here along with the three volume work. Abel and Lewis have managed remarkably well in recruiting leading scholars of independent reputation and at the same time holding them to a reasonably common sociological agenda so that, within the limits of the subject matter, the various studies are parallel, complementary and comparable. This remarkable feat of editorial leadership makes it possible to comment upon the enterprise as a whole as well as upon individual studies.

The enterprise as a whole is marked by both the strengths and weaknesses of its sociological provenance. As sociology, it is certainly ground breaking. Indeed the authors of most of the country pieces rightly complain of the absence of any but the most rudimentary and fragmented previous studies. The common law and civil law volumes present basic demographic data on the lawyers of some eighteen jurisdictions, and a historical description of the evolution of the membership, legal education, practice, economic and social status, organization and discipline of the bar in each. As sketchy and incomplete as this data collection often is, given the absence of previous work in the field and the difficulty of capturing all the facets

* James W. and Isabel Coffroth Professor of Law and Political Science, University of California at Berkeley. 
of a large and diverse profession, this huge collection of parallel data is an enormous advance in sociological knowledge.

Indeed a rather common pattern emerges for the modern industrial nations to which the volumes largely confine themselves. After various growths and contractions in earlier centuries, whose particular causes cannot be easily identified, the legal profession in most countries became rather stabilized in numbers and nature of work. Early in the 20th Century, the profession settled into a quite rigid and formalized system of educational qualifications bolstered in many countries by an apprenticeship, enjoyed moderately high income and prestige and a firmly middle class position, and recruited to a considerable degree on a father to son basis or at least from sons of the executive and professional class. World War I and the depression caused blips but not fundamental changes in the data. In the 1960 s a major change took place which has greatly altered this picture. The immediate cause of the change is clear, although the deeper causes and some of the reasons for the directions of change may be in dispute. The civil law countries had traditionally imposed a university law degree requirement as the basic entry prerequisite to the profession. With minor variations, exceptions and alternative routes, the common law world had come to the same position shortly after the end of World War II. After the war demand for and availability of university education suddenly expanded very rapidly. In many nations a very large proportion of the new students who did not choose science based curricula chose law, and even in those nations in which the numbers in law were not disproportionate, they were very large in absolute terms. The great 1960's surge of male law students from majority cultures was augmented or at least sustained by a surge of women and a trickle of minorities in the 70s and $80 \mathrm{~s}$, although class background changed very little. Although many law students did not complete their degrees, and many of those who did but did not enter the profession, the result has been a large shift in the distribution curve of the profession toward younger, more often female, more often salaried rather than self employed, and more often marginal practitioners and generally toward more persons experiencing difficulties gaining a professional foothold. At the same time the educational floodgates opened, in some of the nations considered other forces led to the growth of larger law firms, the growth of in-house counsel and growing competition from other professions such as accountants and management specialists. The overall result is a complex one in which the absolute size of the profession is way up and there are significant numbers, particularly majority males in their forties and fifties, who are enjoying considerable prosperity. However, there are also large numbers of younger law degree holders who appear to have been marginalized. It is not clear that law has been holding its own in the post World War II development wave. 


\section{The Professional Project}

Abel and Lewis have attempted to make sense of all this essentially by drawing on the Marxist vein of the sociology of professions literature. They sought to organize this whole scholarly endeavor around an approach to professions that takes the "professional project" as central. The "professional project" is the effort to achieve a monopoly position from which monopoly rents can be collected to enrich those enjoying the monopoly. The keys to this monopoly enrichment are control of entry into the profession, successful assertion of exclusivity of competence to perform some distinct services, and insuring demand for those services. In short the "professional project" is enrichment of its members through controlling supply and demand. Through the lens of "professional project," the situation of the legal profession at the verge of the 21st Century is quite dubious. It has lost control of supply to the government which controls the number of university degrees. It is losing exclusivity to tax accountants, business managers, bankers, real estate brokers, and others. Although as a political interest group it can lobby for an increase in demand through government funding of legal services, it must vie with other interest groups for a share of tax dollars. The results of a failing "professional project" are already to be seen in the increasing proletarianization of younger lawyers, that is in the shift to salaried, supervised, routinized employment in industrialized office settings and/or part-time and marginal practice.

Although Abel and Lewis clearly initially set up the "professional project" as the guiding concept of their scholarly project, they did not swear their contributors to a loyalty oath. Some specifically attack the project model and others take an agnostic position toward it. As we shall see later, Abel and Lewis themselves come to have some considerable doubts about it. Indeed one of the useful aspects of these volumes is that they present something of a dialogue about the usefulness of the whole "professional project" approach. The data developed in these volumes suggests some fundamental difficulties. The first involves "project" as an empirical theory of human behavior. The data suggests that lawyers have not been consciously motivated either solely or perhaps even principally by a desire to increase their incomes by building a monopoly. They seem to have been motivated as much by considerations of prestige as income and frequently opted for the former at the cost of the latter, both individually and collectively. Perhaps the project notion might be saved here by a "neo" Marxist move of conceding superstructural prestige a place along with substructural income in the cause and effect chain. Even that move, however, will not explain the large number of instances in which lawyers appear to have been indifferent to both supply and demand control, leaving them entirely to other social forces.

Another way to save the project concept is, of course, to state it in purely structural rather than behavioral terms. Then it does not 
matter whether lawyers ever actually acted to achieve the project. Where the demands of the project are satisfied, for whatever reasons and through whoever's actions, the legal profession exists. Even from this structural standpoint, however, the project concept may not be very useful. Several of the contributors present data that suggest that both supply and demand have simply fluctuated over time, sometimes independently and sometimes not, and in response to a wide range of historical contingencies. Under a structural project lens, it would appear simply that the legal profession sometimes has become "more" professional and sometimes less in various countries at various times and under various circumstances, or more simply that sometimes more people have made more money as lawyers and sometimes less as a result of circumstances quite beyond their control or understanding. If the bottom line of "project" analysis is "Sometimes I'm up, sometimes I'm down," why bother with project? More fundamentally, the word project ultimately sounds in action and intention, not structure. There simply is not enough data to positively support the theory that the legal profession is characterized, let alone defined, by a striving to achieve monopoly rents by supply and demand control.

\section{THE SOcIOLOGICAL TRADITIONS}

The reason for Abel and Lewis' inclination toward project analysis is to be discovered in Abel's introduction to the British volume. Here we get a very clear insight into the difficulties of the whole Lawyers in Society endeavor. It is conceived of as a subcategory of the sociology of professions and, therefore, as dependent upon one or more of three traditions of the sociology of the professions: Weberian, Marxist and Durkheimian (structural functional). Abel indicates that his own volume is basically Weberian with some Marxist and structural functional aspects, and that can also be said of the entire endeavor. In fact, it may be said of the whole endeavor that it is Weberian and Marxist with almost no Durkheim. Moreover, Weber here is largely simply a surrogate for Marx. For Weber in Abel's version, which appears to me to be essentially fair, treats professions as economic categories in an entirely Marxist way, but simply without the grander aspects of Marx's historical march of the class struggle. Weber employed in this way is simply micro-Marxism, separate from, but not incompatible with, macro-Marxism. To the degree that the participants are Marxist, and many of them are to a substantial degree, they face the deep embarrassment that Abel himself points out that Marxists face. Marx teaches that as capitalism progresses it drives the population increasingly into two opposing classes, capitalists and workers. Those classes are defined by their relations to the means of production, owners and non-owners. Real developments in capitalist societies, make hash of Marxism. The most important of these is the emergence of a large middle class, much of whose wealth, power and influence depend on the ac- 
quisition of the capacity to deliver skilled services rather than the possession of capital. The result for dedicated Marxists is that they must pile neo upon neo in order to save Marx's hide. Abel himself and many of the other contributors to these volumes are deeply involved in neo-Marxism. As a result there is a deep urge among them to emphasize the "proletarization" of lawyers when they can find it and consequently to concentrate on the low end of the trade rather than the high end. And for the same reasons there is a parallel tendency to deny the obvious, that is the centrality of the acquisition and provision of a distinct skill to defining the profession. For the more that centrality is recognized, the more Marx's nose is rubbed in the irrelevance of ownership of the means of production to social authority in post-industrial states.

The enormous down playing of education and of skill as central to the legal profession that pervades these volumes is also explained by Abel's most revealing treatment of the Durkheimian or structural functional tradition. Abel notes that this tradition develops a sociology of professions largely built up of identifying traits distinctive to each profession and/or common to all of them. One such trait, of course, is education and another is specialized skill. For Abel, however, this Durkeimian tradition, as exemplified in the work of Parsons, is essentially static, by which he means anti-Marxist, and an apologetic for the professions. It is because emphasis on such traits as education and skill is identified with a sociological tradition that appears to be allied with the right, while nearly all of the contributors to these volumes are of the left, that education and skill are consistently deemphasized as aspects of the "professional project." Or more precisely, the "trait" approach to professions tends to put them in a good light. The Weberian approach, defining professions in terms of success in monopolizing a segment of the service market and collecting rents, that is unearned income, puts them in a bad light. The Marxist approach proves more embarrassing to Marx than to the professions. Therefore if one is on the anti-capitalist left, first preference goes to Weber, second to Marx and structural-functionalism runs a very poor third.

Nevertheless Abel and Lewis themselves eventually find the project agenda so oppressive that they produce countervailing addenda about the legal profession having something to do with law. A number of other contributors also attempt to relate lawyers to law, politics and government. But the great weight of left-oriented sociology presses down on the whole endeavor and almost entirely squeezes out any consideration of legal knowledge as a defining characteristic of the legal profession.

Moreover the whole endeavor is so concerned with the professional project defined as seeking income and status through market control and so concerned with debunking the "ideology of meritocracy" of "liberal capitalism" (The Legal Profession in England and Wales 289) that it does not concern itself much with what lawyers do. Instead it concerns itself a lot with who they are in terms 
of social class, background, ethnicity, gender, education, family background, etc. and their current income and status.

\section{Big LAWYERS AND LiTTLE LAWYERS}

Abel's chapters on Britain and the United States in the common law volume and his volume on Britain are, of course, largely organized in terms of the project. He sees the relatively sudden growth in the numbers of young law graduates as a breakdown in supply control and one caused by the loss of the entry gate to the universities and thus ultimately to government. He also sees a weakening in the monopoly. On the one hand the traditional services of lawyers to individuals in such matters as divorce, the transfer of real property and personal injury are in decline as the state intervenes to simplify the tasks, transfer them to non-litigational processes and/or authorize such non-lawyers as real estate brokers to perform them. On the other hand, in their services to business, lawyers encounter rivals such as accountants, management consultants and investment bankers. The result, as Abel sees it, is the increasing prospect of too many lawyers chasing too few service opportunities and thus a weakening in the professional project, and the profession's assertion of independence as a social institution.

A number of other contributors take up Abel's concept of "project, most notably Alan Paterson who sees the Scottish and Canadian evidence as refuting it. Whether asserted or denied, this concentration on project tends to force us toward statements about the law profession as a whole, thus requiring us ultimately to suppress the basic contemporary dynamic of the legal profession, a dynamic of divergence between organization serving and individual serving lawyers.

One major element in that dynamic is explicitly addressed in nearly all the national treatments. With the exception of the United States, which had opened educational opportunities much earlier, both civil and common law countries greatly expanded higher educational opportunities after World War II. In the civil law countries where the university degree had always been the ticket of entry to the profession, this expansion almost automatically resulted in dramatic increases in the number of lawyers. By the time the great educational expansion occurred in common law countries, apprenticeship had largely been replaced by university degrees, and so there too the increase was automatic. Because the educational expansion was sudden and because the general expansion was soon followed by a special expansion to women, the result has been an age bulge of young, underemployed practitioners-a substantial number of whom are women. At the same time the traditional bread and butter of the solo practitioner, divorce and conveyancing, has been declining.

On the second major element in the new dynamic, the chapters are far from silent but are less focussed. Everywhere in the world 
large law firms, with considerable degrees of internal specialization are growing. These firms are engaged in providing services to businesses rather than individuals. In part because of the generally very high levels of business activity, in part because of increasing levels of government regulation by law, and probably for many other reasons, these firms have been making a lot of money. It is at this point that the "project" approach begins to lead us astray. The individual chapters, having rather well presented these two diverging law practices, then tend to conclude with some general treatment of the overall income level and economic prospects for the profession as a whole. And the two developments tend to average out to either the fairly positive picture, as expressed by Paterson, that law has its ups and downs but over time rolls along pretty well, or alternatively as expressed by Abel, that the lawyers have now lost control and are moving toward proletarianization.

It may be more useful to concentrate on the difference rather than averaging it away. Particularly in the common law countries, law has always been a somewhat stratified profession. No one ever thought that the country solicitor and the London barrister were in the same league. It may well be that we now face far greater and more sharply defined stratification than that to which we are accustomed. A lot of young struggling lawyers may turn into a lot of middle aged struggling lawyers bereft even of prospects and so even more clearly of a lower order. We also confront, and probably will continue to confront, a perhaps smaller but highly visible contingent of lawyers who are getting moderately rich and are at the forefront of economic and social life. In the face of such lawyers, will anyone be able to say that law as a profession has declined? Perhaps, but it is to these great differences between two kinds of lawyers rather than to an overall census like approach to the profession that we must turn if we are to glimpse something of the future stature of law as a profession.

In addition to this great divergence another factor seems to be central to the dynamic of legal professionalism, and it is with this factor that these volumes are most uncomfortable. Most of the country studies note certain declines in the economic opportunities of solo practitioners, the growth of business oriented large firms and the rivalry of other professionals in providing services to business. Shortly we will have occasion to note the difficulty of the civil law chapters in handling house counsel. The common law chapters are also very light on this topic. This inattention is no doubt largely due to the dearth of empirical research on the topic. In many of the countries studied, lawyers employed by business enterprises may not, do not, and/or are not required to join legal professional associations and so are easily lost track of, even as statistics. Nevertheless this inattention, and indeed even the dearth of data, are themselves symptomatic of a larger hiatus in studies of the legal profession. 


\section{CoRPorations aND the Legal Elite}

It is to the structure and process of business, not of law, that we must look to understand the current professional fortunes of lawyers. The real modern threat to the legal profession has already come and gone and does not involve the sudden deluge of law students of the $60 \mathrm{~s}$ and $70 \mathrm{~s}$. That threat was the vogue in vertically integrated corporations of the 50s. For a time business strategic theory favored the vertically integrated firm for a number of reasons, among the most powerful of which was that such integration internalized coordination problems. Thus internalized, they could be resolved by hierarchical command structures, centralized staff and planning functions and the top down discipline imposed by executive career patterns oriented to movement upward in the integrated firm rather than loyalty to a particular sub-unit. In short the winning business would be the Weberian business. In such a vision tremendous attention is paid to boundaries and boundary maintenance. Whatever the firm needs must be brought in-house and whatever it doesn't must be shoved out doors. There is also tremendous attention to loyalty. One is either with the company or out. It is these developments that spawned both Whytes', Organization Man, and Hirschman's refinement, Exist, Voice and Loyalty.

These developments created a general problem for all professions and a particular one for law. If we deviate from Abel's economic view of a profession as a supply control endeavor to a social psychological view of a profession as self-identification with a group which is itself defined by identification with certain values and institutions, then the threat to professionalism posed by vertical integration is obvious. To the extent that the firm requires professional services, they must be brought in. Yet any element of such professionalism that does not serve the firm must be shut out. The professionals integrated must be loyal exclusively to the firm and must seek future advancement not in the specialized sub-unit they have entered but in the general management hierarchy. In an important sense then the professional was integrated because the firm needed his or her professional services, but once integrated, the very identifications that define professionalism were required to disappear.

Thus the vertical integration of many engineering based industries did create a crisis in the engineering profession from which many of the vertical integrators such as General Motors are still suffering. The best and brightest engineers left engineering for management. It might have been anticipated that the result would be a strengthening of the engineering orientation of such companies. Quite the contrary. Because the engineers were required to entirely transfer their loyalties from their "outside" profession to their inside company, the result was not the transfer of engineering perspectives to management but the transfer of the brains of the company from engineering perspectives to management perspectives and the downgrading of engineering skills. In such firms the engi- 
neer who stays an engineer or the chemist who remains a chemist is a loser who finds him or herself at a middle aged dead end in the company. Such professionals also usually find that in the process of serving the company over many years their professional identifications and skills have sufficiently eroded that they cannot easily "exit" back to the "outside" profession.

The centrality of these developments to the fate of the professionals in all industrialized countries is why I lament the only peripheral treatment of "house counsel" in both the civil and common law volumes. For the growth of the house counsel segment of the profession and the degree to which it has or has not become "integrated," is the lawyer side of this more general professional crisis.

The special crisis for the legal profession posed by vertical integration is obvious. If one of the central virtues of vertical integration is that it solves the problem of coordinating independent, equal entities by transforming them into hierarchical, command relationships, then vertical integration eliminates lawyers almost entirely. The general does not need a lawyer through whom to speak to the captains. He speaks to them through colonels. Or, to use a different metaphor, vertical integration is yet another of the 20th century movements from contract to status and thus eclipses the central role lawyers play in liberal contract regimes.

If industrial and post-industrial economies had been fully vertically integrated, the legal profession would indeed have to worry as much as these volumes think it must about the erosion of divorce and conveyancing business because that indeed would be about all that was left. Nearly all the other economic relationships to which law attends and on which it depends would be handled by internal management memoranda in a stream of hierarchical communication in which lawyers were most unwelcome. Only a kind of corporate judge advocate corps would remain to court martial the occasional dissident manager. Somewhere at the top of course, the cartels would have to deal with one another and with the government. The experience of Japan, Sweden and Germany have shown, however, that such dealings can be handled quite successfully without many lawyers. Bankers, rather than lawyers, tend to become the central coordinating figures.

This potential crisis for lawyers has now passed not because of anything related to legal education, entry into the profession or indeed anything that lawyers did or didn't do. It has passed because modern economies have changed and business strategies have shifted in response to those changes. The growth sector in contemporary economies is obviously not in the heavy industrial sector where vertical integration flourished. And even in some of those sectors the Japanese have shown us that techniques may be developed that more efficiently resolve coordination problems than does in-house ownership of all suppliers. Current theories of strategic management are about as far as they can get from the old concern for boundary maintenance. The successful firm is not the well 
bounded, integrated firm. Instead belief is in the "open" firm that constantly searches for and rapidly exploits new profit opportunities by every sort of organizational arrangement that profit seeking minds can envision from fully in-house divisions to "skunk works," joint ventures, majority share holding, minority participation, licensing, contracting and subcontracting, $r$ and $d$ cost sharing and/or open or tacit, parallel subsidy seeking. In short, business strategy has moved back from status to contact, from hierarchically issued commands to negotiations between independent, if often very far from equal, units. Even the special variant on vertical integration, the "national champion" or "national flag ship" firm which European governments have so often encouraged, is now under attack from the European Community.

All this is not, of course, to say that the world has arrived entirely at many small firms competing in an open market place. Merger mania, the multi-nationals and all that are too much with us to make such a claim. Central, however, to this very merger, multinational movement, is the "open" strategy, we have just been examining. The efficient multi-national, and the big buck merger king, are not seeking neat, well bounded, vertically integrated, self sufficient entities designed to operate an exclusive process of production from raw materials extraction to consumer marketing. Rather it or he/she is a bundle of capital backed intelligence seeking profit opportunity wherever and however it is to be found. Moreover we are all becoming increasingly aware that below the headlines, the major growth is the vast proliferation of small and medium size companies that provide technological innovation and/or nitch filling. Even with sufficient attention paid to the huge and partially integrated multi-nationals, the most active and productive segment of the economic world in which we live is not one of office memoranda from upstairs to down but of deals. And where there are deals there are bound to be lawyers.

Many of those lawyers are going to be in-house lawyers for the deal making firms. But the deal making in-house lawyer is in quite a different position than the judge advocate of the vertically integrated firm. His or her life is lived not in-house with the managers, but with the lawyers of the other deal-making enterprises. In a world of contractually established rights and duties, the lawyer retains the kudos that must inevitably be lost eventually in a world of hierarchical command. In a world of deals rather than commands, we all share and value the lawyer's ideology of law, that is we all must believe in a set of rules of the game to govern our deal making. Otherwise the deals could not be made. Even if all the lawyers were "house counsel," this kudos would remain. Of course, in the world of deals, which by their very nature are episodic, complex, extraordinary, and require sudden, rapid rises and falls in the need for highly exotic legal services, the big outside law firm enjoys considerable efficiency advantages over house counsel for the deal making enterprises themselves. And these large deal oriented law firms are 
themselves very powerful, institutionalized purveyors and protectors of lawyers self-identification and the values that lie behind that identification.

Perhaps this concentration on the large, deal making law firm will appear ethno-centric to the readers of this journal. The large firm serving nationally and internationally oriented business is, however, a growing phenomenon world wide, as is the multi-national law firm. The peculiar animosity of French lawyers to business and the peculiar animosity of Italian business, and indeed of all Italians, to lawyers and courts, tends to obscure this growth to some European readers, but it is occurring even in Europe. Chapters in the common law volume attest to a similar growth in Canada and Australia.

It is here that the generally leftist persuasions evident throughout these volumes lead to certain missed opportunities. While those persuasions lead to silliness in only one of the chapters, that on New Zealand, it is difficult for those who do not wholeheartedly embrace contemporary capitalism to focus sufficient attention on the large firm. The volumes are not only to the left but basically sociologically oriented. (Perhaps I have committed a redundancy.) Although sociologists are big on social stratification, sociology as a discipline is over-committed to looking at the whole world rather than the world of elites. And because the rest of us look at elites so much, sociologists tend to overcompensate and look too much at the rank and file. Perhaps if these volumes had wholeheartedly embraced the big rich lawyer in the big, rich firm as the true keeper of the professional flame, they would have come to a more accurate assessment of the current status and future prospects of the "professional project".

It may make some significant differences to various national legal and judicial systems if we shortly have a bulge of middle aged, substantially female, underemployed lawyers. Such people will no doubt contribute to running up the transactions costs of many public policies, may get us to divert some public expenditures from other services into legal services and may, by their lights at least, achieve some greater measure of social justice or at least some greater prevalence of left ideology. From the standpoint of the continued existence and status of the legal profession as a legal profession, all of these people may make no difference at all. If the big firms disappear to be replaced entirely by house counsel who are mere employees loyal to the corporation rather than their profession, that may make an enormous difference. On the other hand, if big firms remain and many house counsel are more engaged in and/or attracted to deal making than to routine janitorial work, the profession of law is likely to remain a very healthy profession. These volumes pay little attention to this question.

The argument I am making is, of course, a highly unpalatable one not only to those on the left but to anyone who believes that the legal profession is worthy of attention not only because it is $a$ profession but because it is the profession of law. For what I am saying is 
that the status and independence of the profession will depend not on its service to law and justice but its contribution to capitalist (and a lot of nominally socialist) deals. That message may not be as cynical as it sounds. It is not overly subtle or perverse to suggest that the same self-definition and the same choice of values that make lawyers the essential hand maidens to capitalist deals make them an independent functioning profession that does contribute to the attainment of freedom and justice. The argument need not be spelled out at length. It is the standard liberal one. It comes down to the point that the deal, the at least partially voluntary mutual agreement among parties that are at least nominally independent of one another, is better than the command delivered on the blue interoffice memo. If the wealthiest, most prominent part of the legal profession is associated with the deal rather than the command, then the profession will continue to define itself and be defined by others in terms of freedom under the rule of law which is the ideological prerequisite of such deal making. Freedom under the rule of law, or regimes of rights, may indeed be mostly a cover for capitalist bourgeois machinations until there is some fundamental change in the political economies of the West. Nevertheless freedom under the rule of law and legal rights are precisely the values that the contributors to these volumes would like to see the legal profession defend. It may be distasteful to many of them but the most significant "contradiction" of modern capitalism as far as the profession of law is concerned, may be the following one. Capitalists today desire "freedom" for themselves because they find it more profitable than command. They are willing to pay a few lawyers a lot to facilitate that freedom. As a result those few lawyers can define and maintain law as a profession, which retains an independence from its employers. And that profession, in order to serve the capitalists, must retain an identification with what the common law world used to call the rights and liberties of the subject.

If the argument I am making is correct, then the profession is safe enough for the foreseeable future. The health and size of its leading component, the deal making lawyers, will, however, vary considerably depending on the deal making style of particular nations, regions and the international economy. And here American ethnocentrism might well lead me astray. American business pursues a particularly competitive, antagonistic, rigid style of interaction. (See Dertouzos, Lester and Solow, Made in America 1989). That style entails the jealous assertion and protection of legal rights and thus peculiarly exhaustive contract negotiations and drafting. The ultimate rights of everyone must be shored up and nailed down under every imaginable set of future circumstances. It is in this tropics of law that the big firm jungle flourishes. Other nations have a more cooperative, or at least more cartelized, way of doing business. They depend more on ongoing voluntary association or covert coercion than does most of American enterprise and so need fewer and less complex legal agreements. So they enrich lawyers 
less. Japan is the model of this allegedly cooperative, but in reality more highly coercive, style. It is no coincidence that it flourishes most in Asian cultures in which ruthless hierarchy has always flourished behind the Confucian mask. Its European parallel has been partially cartelized economies in which similar coercion could be exercised either by the giant companies themselves or by a coalition of the cartels and the government. Germany is one model with the banks as the key coercive instrument. Sweden is another with the unions joining government and the enterprise giants. Yet the current European scene looks more and more American and, for all the talk of multinationals, the development of the European community and of the international economy would seem to presage more and more deals between more and more actors who are not firmly placed in well established coercive hierarchies where a smile or frown from on high is more effective than a contract. At least to some degree the economy of capitalism is moving in the American direction. To that degree the legal profession will flourish.

Of course what I have provided is a top down view of profession to counter the natural tendency of the sociologically inclined to provide a bottom up view. I do not mean that such matters as low average income and high rates of un- or underemployment are insignificant matters. They would be most significant, however, if the legal profession were a socially democratic one. For if it were recruiting generally from the entire socio-economic spectrum, then its general economic fortunes would deeply effect the numbers and quality of its recruits. Across the civil and common law volumes there is quite general agreement that recruitment to law is not open and general, but is heavily skewed to higher income professional strata and even to those with family connections to the bar. In such a situation the bar is unlikely to experience substantial difficulties in recruiting a sufficient number of high quality applicants to replenish the highest stratum of its own ranks. If that is true the top of the profession of law will continue to flourish in terms of economics, social prestige and positive self-identification and assessment. If the top continues to flourish, the rest really doesn't matter, at least in terms of the real professional "project", or so I would argue, although clearly I am using the word project somewhat differently than does the sociological tradition.

\section{CORPORATIONS AND LEGal Elites IN THE Civil LAW WORLD}

The volume on civil law lawyers contains an introductory chapter by Abel and eleven short chapters each devoted to the lawyers of one civil law country. Each country chapter contains a brief history of the profession and information on the various law jobs it does, qualifications for and limitations on entry, size, growth, class and gender distribution, earnings, economic prospects, bar organization and nature and organization of practice. There are chapters on most of the nations of Western Europe, Japan and two Latin American 
countries. With the rather striking exception in some respects of Italy, a relatively clear common pattern emerges. The opening of the universities to a much wider range of students that occurred in the 60s flooded the law faculties with masses of students, the bulk of whom chose law because they did not have the technical competence to choose anything else. Most law students receive relatively little education and most of what they receive is rather dogmatic. The failure rate is high. The flood occurred at the same time that the status of women was changing dramatically throughout the Western world so that about thirty to forty percent of the new and much larger generations of lawyers are women. The difficulty of actually getting an education, passing examinations, finding an apprenticeship and acquiring a practice have dampened the changes in absolute numbers and class composition that might have been expected from the flood. Something like a third to a half of even the new lawyers, and undoubtedly a much higher proportion of the eventually successful, are the children of professionals and civil servants. After very sharp increases, growth curves are now flattening out in most of these countries. The supply side push had been partially matched by a demand side pull created by post-World War II economic growth which has also flattened out. The result is a relatively prosperous and economically stable bar but one with income rather heavily concentrated in the older generations. Because national bars have not vigorously pursued new opportunities in business counseling and/or legal services to the poor and have done relatively little by way of specialization or the development of the large American style firm, a majority of lawyers remain solo practitioners, heavily tied to litigation, engaged in low volume, high priced, non-advertised service provision and, therefore, heavily dependent on divorce cases. (The drawing of wills and simply contracts and real estate matters which are a staple of solo American practice are largely handled in civil law countries by a special branch of the profession, the notaries.) Younger generations are markedly underemployed. Part of the influx of young women may prefer underemployment, but there is considerable anticipation that younger lawyers will take political action to create expanded legal aid for the working class and/or legal insurance for the middle class. Italy experienced the same flood and the same consequences, but the lack of confidence in litigation in Italy is so high that most lawyers handle fewer than ten cases each year. Their incomes are only slightly above the national average and many have second jobs.

The most remarkable theme that emerges from this volume, at least for an American reader, is the extremely incomplete institutionalization of law as a profession in European nations. It is quite appropriate and comprehensible for any American who holds a law degree to say "I am a lawyer, but I don't practice. I'm in business." Or he or she may say "I'm a lawyer. I work for General Motors." Or "I'm a lawyer in the California Department of Welfare Services." For both lawyer and non-lawyer Americans, anyone with a law de- 
gree, or at least anyone with a degree who has passed the bar examinations, is "a lawyer" and remains "a lawyer" no matter what he does for a living. While all Americans recognize that there are many kinds of lawyers doing very different things, "lawyers" they all are, and they are perceived by themselves and others as forming a distinct and singular professional entity. Every one of the European chapters begins with the warning that the category lawyer is not distinct and singular.

This absence of secure institutionalized identity in turn becomes crucial to understanding why lawyers are so much more central to American than to European society. That difference in centrality stems almost entirely from the differences in the degree to which American and European lawyers have come to participate in the affairs of the corporate enterprise and its regulation by government, which are central to all industrial or "post industrial" societies. American lawyers are at the heart of American business and government regulation of business. European lawyers are not. This volume gives us many clues as to why not. Indeed it allows us to identify five basic why nots.

First, the European law degree is an undergraduate degree and one of last resort. It is undertaken by masses of students as the nontechnical degree program that will justify their being at the university and then serve as a kind of minimum, general job qualification. Thus Europeans are confronted by masses of persons with law degrees who certainly aren't lawyers, but are simply university graduates who they call "jurists." Education does not identify or set apart the legal profession in Europe as it does in the U.S.

Second, even those European law graduates who enter law make an early decision to enter either the civil service, the judiciary or private practice. With some notable exceptions, there is almost no subsequent transfer from one to another and traditionally the civil service wing of law enjoyed the highest prestige. The European government lawyer is a civil servant-lawyer, with civil servant definitely coming first and with no sense of identity with private practitioners. The America situation is of course the reverse. The model of the whole profession is the private practitioner. The government lawyer is a lawyer who happens to be practicing for the government now and will probably be practicing privately later. And the judge is someone who used to practice privately and was appointed to a judgeship because of success in private practice.

A third and closely related phenomenon is that European "advocates," that is private practitioners, have traditionally and defiantly defined themselves as a "liberal" or "free" profession. Such professionals may not be salaried employees. They must bestow their services freely on those who need them. Thus the difficulty with "house counsel." Any "jurist," that is law degree holder, may be the "law person" for his particular managerial unit. Legal calculations are often not sharply distinguished from other managerial calculations. Of course many American managers must take law 
into account, but the very fact that they don't have law degrees and see legal training as a distinct and post graduate training different from their own renders the lawyer who works for their company still very much different from themselves, still very much a lawyer which they are not, and still the person who must be consulted on "real" legal questions. And no less a lawyer because he or she is a fellow employee. In Europe house counsel remains an anomaly that cannot be easily fitted into the liberal profession of law.

The liberal profession tradition is part and parcel of the distinct and traditional anti-governmental, litigation oriented and rhetorical stance of the European advocate. This stance is a fourth factor in the European lawyer's displacement from corporate enterprise and its regulation although here we must distinguish between roughly the Latin and Germanic nations. In the post-French revolutionary world, French and Italian lawyers came to define themselves as the defenders of the legal rights of the citizens against the pretensions of authoritarian governments and surviving ancien regime privilege. The rhetorical tradition that is the very origin of civil law took on a new stature as the courtroom became the forum for defending bourgeois liberties. Law was a "free" and "liberal" profession not only in the economic sense of self-employment but in the political sense of resistance to government.

This liberal stance not only emphasized that governmental legal officers could not possibly be in the same profession as the advocate, but it also cautioned private practice lawyers from being drawn into the growing and increasingly complex mass of government regulation. The Civil Code and the courtroom was the arena for defending the rights of citizens. In remarkable opposition to their own economic interests, European lawyers willfully and deliberately gave away the growing areas of labor, tax and social welfare representation to non-lawyers. And while today administrative law is part of the French and Italian law curriculums, most private practice lawyers still seem to have as little as possible to do with public law.

In the German speaking countries, the situation was somewhat different, although even there private practice lawyers played a disproportionate role in liberal political movements. In most of these countries, legal education itself, and the nature of the apprentice training system, has tended to identify state service as the very model of the lawyer's work and to acquaint all future lawyers with the actual workings of government administration. In these nations private practitioners have been less prone than in France and Italy to divorce themselves from business regulation and social welfare matters and, at least in Germany, a certain "Americanization" has occurred-particularly in the growth of some larger firms deeply involved in regulatory matters. In the Netherlands and in Scandinavia there also seems to have been some developments of legal representation in social welfare matters.

German speaking private practitioners have less of an oppositionist tradition than their Latin speaking counterparts and so less 
of an inclination to stay as far away from government as possible: Yet the very absence of such a tradition probably makes them less vigorous champions of private clients against government wrong doing than they might otherwise be. Neither the southern nor northern European private practitioner can quite capture the mix that seems to make American lawyers so comfortable in the government regulation area. The American lawyer may have been both in and out of government service. Even if not, he or she does not view the government's lawyers as a different kind of lawyer or the government as really a different kind of party, either to be particularly opposed or respected. The government regulation matter is just another law matter, grist for a professional mill in which the lawyers on both sides are doing the same job as one another and the same job as they would be doing for two private parties. Perhaps this all boils down to the old Diceyian notion that the rule of law could only be achieved if the government official were treated as simply a normal party in a private lawsuit. The deliberate common law refusal to distinguish between private and public law may especially arm the English speaking private practitioner for practice in the public sphere.

A fifth and final factor, and again perhaps only another way of stating the tradition of a "liberal" profession, is the European lawyer's marked distaste for business life. The law person for a business is likely to fall into a salaried or otherwise dependent role. Perhaps even more fundamentally, law persons for firms or corporations can hardly keep up the pretence that they are bestowing a gift of learning and receiving an honorarium. Particularly for the French and Italians, law is not only a free and learned, but a noble profession, almost in more senses than one. A lawyer was, and is, better than a shop keeper and almost as good as a man with a sword. In the late 19th and early 20th Century the French bar took the most vigorous steps to keep its members away from commerce, and that tradition only waivered after World War II. The various remnants of the notarial tradition, and the cluster of offices akin to the British solicitor (procurator, etc.) also kept advocates away from contract and real estate matters that would have drawn them into the growing corporate sector. The world is now changing very rapidly, but until very recently, commerce, no matter how financially rewarding, was not a good color for the robe of the lawyer. (Indicative of the changes now occurring, however, is the fact that, apparently by a deliberate evasion of the statutory language, Spanish house counsel are now enrolled among the abogados.)

So with many variations, and particularly a north-south gradient, the picture that emerges from this volume is that the profession is still struggling to find a way to tap into the enormous pool of lucrative legal concerns that arise in the course of relations between business enterprises and between government and business enterprises.

Perhaps the volume somewhat exaggerates this picture for two 
reasons. The first is its basis in sociology and the inclination toward averages in sociology that we have already noted. Under editorial supervision, the country reporters to this project have fulfilled the obligation of describing the whole profession of private practice with various addenda on other lawyers. This perspective may be both too broad and too narrow. It makes it impossible to even seek to identify a lawyer elite of highly successful heads of the few larger firms, government lawyers, professors, house counsel, senior judges, and distinguished specialists. Such an elite may or may not exist at all, and may or may not be deeply involved in corporate-government affairs. From the standpoint of law or politics, the existence and evolution of such a elite is far more important than the number of women divorce lawyers in the Paris suburbs, but little knowledge about such an elite emerges from this volume.

The second reason for the perhaps excessive concern for the run of the mill lies in the "comparative" aspects of this volume. The editors are not to be faulted for the standard sin of comparativists who usually simply proceed country by country rather than by comparing anything. Both in the introductory chapter of this volume and in the whole of volume three real comparison is done. Nevertheless organizing this volume country by country leaves out transnational institutions. The role of law, courts and lawyers in the European Community has been quite momentous. No doubt the average European advocate has been almost totally untouched by these developments and concerned only to the degree of worrying about "foreign" lawyers moving into town after 1992. Nevertheless an EC law practice has arisen and one that draws some lawyers very deeply into commercial and public law matters. The EC must surely have provided much new grist for the leading sector of the bar, but we see almost nothing of it in this volume.

\section{Why NOT LOOK AT THE BIG LAWYERS?}

Perhaps all this comes down to the reviewers' normal tendency to criticize authors for not writing some other book than the one they did. The next step after counting lawyers may be to study lawyers who count. The American findings that show lawyers constituting two strata, one serving corporate clients and the other individuals, are frequently cited in the comparative studies of volume III, but they are generally ignored when the various contributors to all the volumes come to consider the professional "project," professionalization-proletarianization theme. The corporate lawyer (1) makes a lot of money and thus achieves high status in societies where money is status-that is all capitalist societies; (2) moves away from "free individual professionalism" (a) as a partner in large firms in terms of working conditions even if not technically (b) as a salaried employee in large firms or in corporate law departments (c) as a sub contractor highly dependent on a few large corporations; (3) has a skills or knowledge monopoly-the regulation of business rela- 
tionships (including relations of business with government) by law even if he is challenged by rivals at the margins; (4) has a specialized education and subsequent reenforcing experience. (1), (3) and (4) far outweigh (2) and give us a flourishing legal profession with a strong sense of self among corporation serving lawyers, no matter what happens to the rest of the lawyers. In those, basically Latin language, nations in which 19th century lawyers rejected business and succeeded in their suicidal quest to keep themselves free of corporate capitalism, the private practice of law is in great disarray precisely because there is a smaller set of very highly paid and therefore high status lawyers to demonstrate the flourishing of the profession.

Under the impact of post World War II international market corporate capitalism such American style corporate lawyers are now emerging certainly in Germany and even in Paris and Rome. In the world of the "deal" but the deal complicated by heavy active and potential government regulation, the corporate lawyer must prosper even if his share of participation in deal making may be higher in some countries than others and even declining relative to the participation of others.

If this is true then a legal profession flourishes even though non-corporate lawyers may suffer various vicissitudes. And what defines that profession-sets it off both in its own eyes and that of others in the corporate world-is a monopoly of a certain body of knowledge based on a monopoly of a certain subject matter education. That all sorts of other people outside the corporate world also have that knowledge or at least that education and (1) do not flourish, (2) do not do law jobs, or (3) do them as government officials does not change the perception of law as a profession within the corporate world.

Thus it is not a matter of there being no law profession. It is a matter of two worlds. In one, the corporate world, there is a law profession defined by skill and assigned high status. In the other world, the left over world of pre-corporate liberal individualism, law as a profession may be declining but basically because that whole world is declining.

Of course much of this analysis can be sandwiched back into Marxism. Faced with the perverse persistence of middle class prosperity, neo-Marxists have defined a new category of "credential capitalists." In post-industrial, service dominated economies, control over the means of providing services replaces control over the means of production as the engine of exploitation, that is of appropriating the surplus value created by the masses. That is why the "project" orientation is ultimately so central to the editors. By characterizing the legal profession in terms of control over a service, it can be neatly plugged back into a post-industrial neo-Marxism model, in spite of the embarrassment of discovering a lot of flourishing non-owners of means of production. In their contribution to volume III, Ivan Szelengi and Bill Martin try various ingenious 
employments of Gouldner and Gramchi to construct one of these neo-Marxist saves. From my point of view all they really end up saying is that when all students tended toward radicalism in the 60s, so did law students and when all students were yuppified in the 80s, so were law students. At the micro level, the large law firm is a Marxist dream, with the partners busily extracting surplus value from the salaried employees, lawyers and non-lawyers alike. To the extent that any lingering chance remains that the neo-Marxist is not persuaded by his own neo-flourishes, sociological averaging reassures us that all will come right in the end, with the lawyers finally sinking into the proletariat. For of course, the concept of credential capitalists, while briefly saving Marxism from the threat of reality, is not ultimately satisfying to Marxists. While it explains away the persistence of a middle class, it does not do away with that class, and as long as that class persists, the ultimate, stark confrontation between the capitalists and the proletariat which is the necessary precondition to revolution does not occur. Thus conveniently enough these volumes tend toward a depiction of lawyer credentialism as a transitory stage on the road to proletarianization.

An alternative Marxist route would be to acknowledge the persistence of a profession of corporate lawyers and to depict them as a small group of persons using their credentials to ascend to the ultimate capitalist elite while all the other lawyers sink into the proletariat. This position can be inferred from and is even occasionally stated in these volumes. What was once a cohesive bourgeois grouping is now shattered by class contradictions and evolves into a small capitalist elite confronting a proletarianize mass. How satisfying. The difficulty, however, is as usual that the more we assign real bodies to the capitalist class rather than treating it as a shadowy white menace, the more it gets to look like a persistent middle class that stays middle because of the persistence of middle incomes rather than any specific control over the means of production or service. That is why ultimately these volumes do not yield to the rather simple and obvious tactic of defining a profession by the situation of its more prosperous members.

\section{Legal KNowledge AND the Legal Profession}

Throughout these volumes there is repeated emphasis on legal education as a gate keeper, but also a rather persistent, if not absolutely consistent, refusal to resort to the obvious, that is to defining the legal "profession" in terms of specialized knowledge acquired and used. Perhaps I am a victim of anti-Marxist paranoia in ascribing these volumes' avoidance of this obvious to its inconvenience for Marxist means of production style analysis. It may result as much from the recruitment of most of the contributors to these volumes from the structural rather than the ethnographic-anthropological wing of sociology. The sociology of these volumes is concerned with placing law as a profession within the "objective" structures of vari- 
ous societies. The perspective adopted is that of the outside observer. An anthropological perspective that asked "what makes some persons feel themselves to be members of a perceived profession?" and "what makes other persons perceive those persons as being members of a certain profession?" might have avoided the obvious less. It is true that the undergraduate and generalized nature of the continental law degree somewhat undercuts the assumption to be found in America, and increasingly in other English speaking nations, that one with a law degree both has learned something special and earns a living by employing what he or she has learned. Nevertheless in most of the world lawyers think of themselves as lawyers and other people think of them as lawyers because they know about law and make use of that knowledge. To say that lawyers in this sense are a perceived group but not a profession because defined as such they do not control supply of and demand for their knowledge is a tautology that we need not accept as particularly useful. If the argument is "well shoe makers perceive themselves and are perceived by others as a group too but they are not a profession," the obvious response is that professions are defined not only by the acquisition and practice of knowledge but by the quantities and qualities of knowledge they acquire and practice. One of the most striking characteristics of these volumes considered collectively, and one of the best evidences of the intellectual leadership of the editors is that this whole approach to professions is tacitly rejected.

\section{Comparative Studies, Legal KNOWLedge and LaWYer Elites}

It is in volume three, the comparative volume that this distanced sociological approach is most crucial. That volume stands as a real tribute to the editors and leaders of the enterprise. Volumes one and two, the country-by-country descriptive studies stand as an enormous accomplishment in descriptive sociology, providing a rich mine of data that, thanks to the agenda setting of Abel and Lewis, is comparable data. Thus the volumes stand on their own as an important empirical achievement. Moreover, the contributors to those volumes are not simply workers in the vineyard but substantial scholars who provide important analyses. Nevertheless were the two volumes, plus Abel's British volume, which is an extended country report along the same lines as the others, to stand alone, they would be subject to the standard complaint about "comparative" studies. Where's the comparison? Abel and Lewis have provided us with a third and comparative volume. To be sure it is not the optimal comparative volume. Such a volume would have been one written by Abel and Lewis themselves consisting of a comparative analysis of all the comparative country by country data collected in volumes one and two. Instead we get a volume three consisting of contributions by individual scholars, each of whom has something 
interesting to say, but none of whom is obligated to make sense of all that has come before.

Obviously it is not feasible to conduct a thorough review of all of these contributions. What follows is a highly space constrained, almost random response to some of the points raised by some of the contributors which unjustly ignores other of the contributions entirely and some of the most important arguments raised by the contributions about which I do say something.

In the lead off chapter Lawrence Friedman offers a characteristically simple and common sensical explanation of the peculiarly large role of the legal profession in American life. In a nation with a large number of small land holdings and few other regimes of authority (e.g. royalty, aristocracy and established church) there must be many law jobs, few alternative doers of them and so many lawyers. When this small holder regime is replaced by the modern welfare, regulatory state there are even more law jobs and so even more lawyers.

In Chapter II Lewis provides a general essay that grows out of his editorial experience with these volumes. As we will have reason to note shortly in examining Abel's chapter, the charm of both these editors is their critical intelligence and their willingness to apply it to their own work. They openly acknowledge the immensity and complexity of their task and the unlikelihood that any particular theoretical formulation will neatly package all of the data. Lewis' chapter is a kind of theoretical putting in scene for the whole enterprise that opens dozens of (mostly unanswered) questions and scrupulously admits the uncertainties, hiatuses, false starts and alternative routes that abound in the work of all the contributors. As both he and Abel also do in a number of other places, Lewis tends to move on from the theoretical stance around which these volumes were actually organized. The "project" theme aimed at a general, cross-cultural, law and society, style of analysis that, given its Marxist roots, carries the ambition of a general sociology equally applicable to at least all industrialized states. Given those same Marxist roots, "project" oriented investigation should lead us to discover certain inevitable, parallel changes in national bars, including their eventual proletarianization, as the history of international finance capitalism rolls on toward the revolution. Yet in a chapter entitled "Comparison and Change" Lewis counsels that we downplay attempts to arrive at a general cross-national theory of the legal profession in favor of historical studies of the particular and, in Lewis' view, highly contingent evolution of particular national legal professions. Comparative analysis will then get us beyond a greater appreciation of each of the particulars to a general conclusion. Indeed even Lewis' vision of change includes the notion that particular legal systems may experience long periods of stability, so that he is not proposing a general theory of parallel change.

When we combine Lewis' commitment to historical studies oriented to the contingencies of individual nation state developments 
with Abel's commitment to "project" spelled out in the chapter immediately following, the rationale of the format of volumes I and II is more clearly revealed. All of the contributions to those volumes are country studies that begin with a historical sketch of the evolution of the profession and go on to a presentation of current education (supply control), demographies, organization and discipline (control of the product of the producers) and stance toward government legal aid (demand control). From Lewis' chapter we discover that organization by country was not just an accident of convenience or sloth. If "project" were indeed the sole centerpiece, then crossnational chapters on various aspects of the ups and downs of the project (e.g. entry control, exclusion of rival professions) would have seemed the ideal organization. Country by country organization would appear merely a concession to the cultural incumbrance that most scholars are more comfortable with national raconteurship than with science. The introductory historical sketches to each national contribution might seem mere humanistic flourishes preliminary to the real sociological science so long as we concentrate on project. Now we can see that volumes one and two live in the tension between Lewis' nationally, historically contingent legal professions and Abel's universal and inevitable, materialist, professional project.

Abel's chapter in volume three is the clearest and most consistent laying out of his project theory. It is interesting to compare it with his introductions to volumes two and to his own British volume that were clearly written later. In those he is far less confident of the "project" concept as a single key around which all the data can be successfully organized. Over the course of experience with this large enterprise even Abel tends to demote "project" to one of several stances that might better inform our understanding of the legal profession.

Nevertheless in this chapter the emphasis on project causes Abel to throw away a key insight and one that probably ought to inform the next generation of studies of the legal profession. Abel writes at page 128, "Generalizations about income are very misleading, however, because lawyers are a congeries of quite disparate occupations." Very true, yet Abel constructs this whole chapter out of various economic and demographic generalizations about the legal profession as if there were one. As a result his conclusions are a generalized pessimism about a generalized profession: loss of control over and consequent high entry; loss of monopoly over services to rival professions; proletarianization through shift from independence to salaried employment, low incomes and increased specialization; and failure to generate new demand. The professional project is failing, he asserts. As we have already noted, if Abel had looked more closely at the disparate occupations and had organized some of the chapters of these volumes around some of these disparate occupations, different and more interesting conclusions might have been reached. 
Much of the pessimism of Abel and others stems pretty directly from the enormous flood of European law graduates that began in the 60s. A crucial question posed by these volumes is, therefore, whether the proletarization tendencies to be found in the aggregate data is a product of deeply structured economic, "control of the means of production" kinds of evolution, the product of a highly particularized and contingent change in government education policy or the product of a fairly long term "democratization of the higher education that produces lawyers. Guy Neave's chapter on education is, therefore, of central importance to the whole enterprise.

He tells a story of expansion and contraction resulting from conscious changes in government policy. European governments deliberately expanded university places greatly in the 1960s under the influence of two bodies of economic theory. The first was a neoKeynsian theory of investment in education leading to economic growth. The second was an egalitarian social welfare theory. The neo-Keysian theory and the very expansion itself necessarily came to imply a shift from the traditional role of universities as purveyors of public sector employees to the role of purveyors to the private sector, if for no other reason than because the public sector could not expand fast enough to absorb the new graduates.

In the 1980s contraction in higher eduction begins to occur, in Neave's view for reasons having to do with the same two economic theories. Neo-Keynsian indirect, general pump priming is in retreat in favor of national "industrial policy" that seeks to directly and specifically foster wealth producing enterprises. Reduced public spending, including reduction in educational spending, provides such fostering by lowering tax burdens on the private, and truly productive, sector. And what education expenditure remains should be channeled directly to those particular kinds of education that directly serve productive enterprise. Moreover the egalitarian thrust of social welfare theory has been blunted by growing sensitivity to welfare costs and the impact of welfare costs and benefits on the incentive systems needed for efficient private sector production. Thus cutting the "waste" in higher education and fine tuning that education to private sector needs becomes central. Thatcherite education policies in England are the most dramatic example. Many such attempts on the continent have been thwarted by student direct action. But continental governments achieve similar outcomes by budgetarily starving the "non productive" sectors of higher education, an approach which leaves the students with no clear target. Moreover very cheap, and thus very undisciplined, higher education, which leaves the few professors free not to teach very much and the huge student bodies not to go to class very much, while both professor and students draw government stipends, is a compromise in the short terms interests of everyone.

Somewhat counter to this picture of direct government policy are a number of other phenomena described by Neave that seem to revolve more around individual life choices. Starting in the mid-50s, 
there was sharp rise in the number of students completing the kinds of secondary studies that are the gateway to university admission. This tendency has continued, and even accelerated. (Some of this change may be attributed to government policies in some countries, particularly shifts toward "general secondary" schooling that allow more student (parents) to avoid very early shifting to non-university preparatory tracks.

The growth of numbers of law students was not invariably proportional to the overall growth in university population and so seems somewhat more a matter of individual choice and somewhat less of government policy. At first law student growth lagged behind university expansion and then tended to grow in spurts. The big spurts perhaps were related to changes in secondary education screening. They tend to come when university admission is opened to more of those who did not receive traditional, academic secondary school preparation. My own interpretation of this data is that law serves as a residual category for students who come to university with relatively little academic preparation or interest and so no inclination to study anything in particular.

Nevertheless, Neave points out that the overall proportions both of law students and law graduates has declined in the last two decades. My own conclusions from his presentation is that the big post-World War II growth of lawyers in Europe has been a relatively minor and unintended consequence of government policies designed to increase and equalize educational opportunity-policies which have now changed again toward placing a cap on higher education. The resulting temporary bulge in the number of young law practitioners, rather than the deep structural evolution of capitalism, is what then leads to the appearance of proletarianization in the aggregate data. That one shot government generated bulge has been prolonged by a similarly one shot, step level change in the proportion of women law students. As the bulge passes it is likely that the perceived proletarianization will pass.

Neave points to one other highly interesting dimension of government policy. European governments have tended to limit enrollments in medicine and engineering but not in law. Neave argues that the state is protecting the professional project of those professions that particularly serve it. But certainly with the possible exception of post revolutionary France, traditionally law was seen as a profession that particularly served the state, and that perception has surely persisted. With the current emphasis on productivity, engineering may well be perceived as the most state serving, but law would not seem to fall behind medicine in that respect. Again my own conclusion would dwell less on deliberate state policy. Medical and engineering education are expensive because the educators involved insist that something more than a small library and a large lecture hall are necessary. Legal education is cheap. There is no need to limit legal enrollments to save money because legal educators do not say they need anything but the large lecture hall and are 
quite content if most of their students come to those halls only occasionally.

Abel and many other contributors seem to agree that the bulge of young lawyers is supply pushed rather than demand pulled. The supply push appears to be the unintended consequence of government educational policies, one of those historical contingencies that Lewis bids us study. Market forces, individual choices and government policies now all seem to be pointed away from further supply increases and indeed toward some reduction in supply. More speculatively it might be argued that business strategies now lead to increasing demand at least for one of the "disparate occupations" of law. Continental lawyers, of course, never had control of entry because they never controlled university law degree granting. So the European scene is not about lawyers losing a "project" accomplishment which they never attained but of their adjusting to changes in government policy which they have always done.

Much of my complaint about the orientation of the Abel-Lewis enterprize to "project" and to aggregate data boils down, I suppose, to the complaint that the enterprise sounds in Marxist sociology rather than in anthropology which would see the legal profession in terms of a shared language and body of knowledge and the perceptions of community that such a sharing create or in political science which would define the legal profession by reference to law and government. Although no contribution to the three Lawyers in Society volumes adopts an anthropological approach, a sudden, curious and radical shift to politics occurs part way through volume three.

This shift to politics is prefigured in Lewis' own chapter two which urges that study of the legal profession ought not ignore the relation of lawyers to law and refers the reader onward to the concluding chapter by the two editors.

Neave's chapter five on education serves as a transition. It treats education as a gate keeper and thus fits the "project" orientation, but given its focus on European education, it is full of talk of government educational policies and thus of the impact of politics on the profession. And then suddenly we get Dietrich Rueschemeyer's chapter 8 "A State-Centered Approach." From that point on all of the rest of the chapters of volume three are politics centered. Rueschemeyer supports and expands on Lewis' earlier point that a comparative sociology of lawyers should reject pure functionalism for a historically and state oriented approach because states always play a major role in shaping the profession and there is a historicity (persistence and autonomy) to the various state structures. Rueschemeyer argues that there is a certain convergence of legal tasks in modern industrial societies but that differences persist; differences resulting from differing roles of the various states in their economies and different historical evolutions of the states themselves. Chapter eight serves as a gigantic footnote to this latter point showing how the different natures and outcomes of the American, Eng- 
lish and French revolutions result in differing legal professions in the three nations.

Rueschemeyer sees the legal profession as flourishing in response to two major historical developments, the rise of capitalism and the rise of the modern nation state. Before pursuing with him, and the rest of volume, this concern for the state, I beg to enter a small aside. Rueschemeyer rates capitalism right up there with the state. He himself does briefly raise the subject of lawyer participation in corporate power (310-11), but quickly moves on. Yet his basic historical account reminds us yet again of the curious, shadowy treatment, or rather lack of treatment of the corporate lawyer, both house counsel and large firm partner, in all three volumes. Reuschemeyer's argument ought to lead to further study of those lawyers who most directly serve and are, therefore, most directly shaped by corporate power and who also, not incidently, are the most prosperous element in the bar. In short, if Rueschemeyer himself provides us with a "state centered" chapter, why has not someone else provided us with a "corporation centered" chapter.

We have already noted that chapter 8 on revolutions continues the state-law-politics approach of chapter 7. Chapter 9 is about neo corporatist theory although the author frankly admits that current professional associations don't fit the theory very well. Nevertheless, Terence Halliday's insistence that the legal profession does not fit Marxist theory because lawyers are not a class and because lawyers hold power as a result of their monopoly over a skill rather than over the means of production is a nice comparison to the desperate attempts of Szelenyi and Martin in chapter six to neo Marxize the profession.

Chapter 10 of volume three is quite the most startling and revealing of all three volumes and might well serve as a general critique of the whole project. It is written by Magali Sarfatti Larson whose own previous work on professions is the central basis for the whole "project" orientation of these volumes. Yet Larson does not concentrate on project. Written by someone not a specialist on lawyers this chapter most clearly grasps the obvious of what lawyers are and what distinguishes them from others. They are specialists in a particular language who gain that special knowledge by training. What they do is speak that language as a means of representing individuals. In this and several other chapters in the "political section" of volume three we clearly see legal representation as a peculiar activity related to but different than political representation-both speak for others but political representatives do and must make choices that are not simply additions of all the individual interests represented. Legal representatives maintain the position of and remain under command of the individual client and transform his/her position only insofar as all translations into another language unavoidably involve some transformation. What does the lawyer represent clients about? Not about everything but only about the relationships defined by law between individuals and between indi- 
viduals and government. Because the public authority expresses some of those relationships in the language of law and the lawyers are the sole specialists in that language, lawyers must play a major role in the constituting of public authority.

While market monopolies are neither unconnected to nor insignificant in all this, the legal profession exists not because it holds a market monopoly created by entry rules. Rather it exists because (a) it speaks a language no one else speaks which (b) it learns by a training no one else gets and (c) it performs a special function, representation in that language of the interests of non-speakers of that language. We shall see shortly that the combination of specialized knowledge and representation will allow us to deal with the central problem for comparison raised in these volumes, that is the large numbers of Europeans with law degrees who don't practice and the large numbers of judges and civil servants (although prosecutors remain a problem). It also pulls us away from worrying about "proletarianization" questions. A lawyer who speaks the language and represents is a lawyer whether his clients pay fees or a salary.

This chapter too is the only one that looks at the big corporation phenomenon head on. Paradoxically it does so because it is a chapter that looks at "the lawyer" instead of "lawyers." Built up as a highly abstracted and generalized analysis of the role of law as a profession in a changing polity rather than looking closely at the large number of real persons who have some claim to being called lawyers, it is easier for the author to see the forest. And in the contemporary forest an awfully big patch is the corporation.

This chapter sees the growth of the welfare, regulatory state and corporations as the two major factors reshaping the profession. The former erodes the public-private boundary which it used to be one of the principal tasks of lawyers to patrol, a task that partly defined their distinctiveness as a profession. With the erosion plus the growth of corporations, what corporate lawyers do "must be political, in the broader sense of an exercise of power and skill that affects large segments of the public." Larson sees the corporation as becoming more and more state-like-both in its increased bureaucratic normalization of rules, procedures and techniques and the imposition of those norms on private citizens. Those norms are imposed less through the coercive mechanisms of law than through the sale of products and services that can only be used effectively if the norms built into them are obeyed by the consumer. (What the author does not note although it fits perfectly with her argument is that the health and safety regulations of modern governments multiply this control of corporate produced things over individual human beings who are forced "for their own good" to use the product exactly as it is designed to be used.)

Clearly the lesson to be drawn from the chapter is that we ought to acknowledge that lawyers divide into two distinct groups, the corporate serving (firms and in-house counsel) who represent "repeat players" and the individual client representatives. The au- 
thor relies heavily on Gallanter and as a result, like him, tends to be only concerned with repeat players versus non-repeat players as such. She does, however, note that lawyers for repeat players play "for keeps"- that the rules they get tend to be enforced rather than symbolic. If we add that a major segment of repeat player lawyering is the play of one repeat player against another, then it becomes clearer that the corporate law sector of the profession is not only worth studying because it is alive and well but because it is so much at the center of political power. Near the end in a number of useful paragraphs, the chapter clearly focusses on this lawyering activity and analogizes it to the "state-constitutive" role of earlier lawyers. And the chapter ends with a call for the study of what "different groups" of lawyers do. Readers of the common sense variety should not be put off by the highfalutin language of European critical political sociology in which much of the message is expressed.

The final chapter of the three volumes is coauthored by the two editors and is entitled "Putting Law Back into the Sociology of Lawyers." The editors have learned a good deal in the course of the enterprize and take an appropriate opportunity to report what they have learned-namely that "project" is not as good a key as they initially thought to unlocking the mysteries of the legal profession. The editors now address themselves not only to who lawyers are demographically and in class terms, but to what they do, and what is distinctive about what they do. And, glory be, that turns out to be something about law. I do not wish to summarize the Chapter here. It ought to be read. It says a good deal that is fairly complicated and quite smart. I do wish to carp. What lawyers do for business clients is mentioned (489), as is the importance of house counsel (497). And at pages 498-499 there is a little bit of an attempt to break up the mass of lawyers into categories on the basis of what they do. Yet there remains a pronounced aversion to breaking out the legal elite, the very prosperous corporate lawyer, and examining that elite as both intrinsically the most interesting, because most powerful, and the key to the fortunes of the profession.

Indeed the denial of the obvious persists to the very end. By page 501 there is finally some acknowledgement that what lawyers know may be important to defining the profession, but even in their discussion of knowledge the editors manage to talk mostly about other things. And in that discussion of knowledge (506-07) they denigrate the role of university education and emphasize practical knowledge gained on the job. It is always curious to find sociologists down playing such a powerful variety of socialization as formal education. No doubt this down playing is the result of an admirable sociological desire to see beyond formalism to what people really do. But one of the vital things that lawyers do is translate varying everyday and technical discourses into a common formal discourse, the one they learned in school. Even from the depths of the back rows of sporadically attended lecture halls and beer hazed cramming sessions, the language of the codes still seeps to the surface of the Euro- 
pean lawyer's brain as does the litany of cases to that of the common lawyer. If we are to put the law back in, eventually we will have to deal with law as a set of formal expressions as well as a set of office practices. That academic lawyers have always erred in one direction does not mean that a sociology of lawyers must necessarily err in the other.

The largest dire warning I wish to issue is not particularly fair to Abel and Lewis. It is a kind of guilt by association. The title "Putting Law Back ..." is obviously a conscious reference to putting the state back in-a move that has become so recently fashionable in sociology. (In political science it is the "new institutionalism.") The state may be brought back in in a number of different ways. Unfortunately in much of the most fashionable writing, it is brought back in as the most misty neo of neo Marxism. The "state" becomes an abstracted, repressive "regime" or they or power that serves as an unspecified residual source of whatever the proletariat suffers from that cannot be accounted for by reference to more direct and explicit exploitation by the owners of the means of production. We must hope that law is not brought back in the same way. A strong dose of Ruescheyemeyer's real historical states that consist of real governing persons, organizations and institutions that do actual, concrete things is to be highly recommended and along with it a strong dose of real laws rather than an abstracted law seen only as the sum of non-market class repressions. What Abel and Lewis write in this final chapter could start us off in either direction.

If Abel and Lewis have frankly acknowledged that they initially rather over invested in project and have come to see the need to look to other things, they have also acknowledged that their goal of comparison may have eluded them. Abel makes this point explicitly in some of the introductory sections that clearly were written late in the game after the country studies had been completed. I have said almost nothing about the common law volume (vol. II). It prompts similar criticisms to those offered of the civil law volume which need not be repeated here. Although the stories of historical evolution told are much different from those of the civil law countries and from one another, the basic modern pattern reported is remarkably uniform. Expansion in higher education generally, leading to more law graduates, sudden movement of women into law schools, maintenance of upper middle class origins, an age bulge of young lawyers who experience low income, salaried status and under-employment, erosion of the service monopoly by competing professions, failure to elicit major new demand, weak professional organization, elaborate but largely ineffective bar self discipline, dark days ahead. There are of course the glitches of the solicitor-barrister split and apprenticeship rather than university law degrees as the entry route in the mother country (pace Scotland and Wales). As Abel shows clearly, however, in his English volume a shift to university degrees has now been accomplished and the latter glitch eliminated. Mrs. Thatcher may shortly eliminate the former. Yet in spite of all this 
parallelism comparisons between common and civil law lawyers appears ultimately problematic to Abel.

When we seek a European (and Japanese) population to compare with the "lawyers" of the common law countries, how do we bound that population given the civil law undergraduate degree versus the common law graduate degrees, and the tripartite legal career patterns of civil law countries versus the more or less common bar of English speaking nations? These volumes, for instance, basically exclude judges from both their common and civil law populations in order to achieve greater comparability, but in the process must exclude a significant segment of the most successful members of the common law bar and one that exerts tremendous influence in its internal affairs. The civil law volume excludes government lawyers, thus reducing its scope exclusively to private practitioners. That makes great cultural sense because in Europe government and private practices lawyers would acknowledge that they held the same degrees, and thus shared a common, minimum expertise in the codes, but otherwise would not readily identify themselves as being in the same profession. The common law volume, for similar cultural reasons, formally includes government lawyers (statistically it would be difficult to exclude them since in some common law countries and states they are usually bar association members and so included in all aggregate bar statistics), but then makes a bow toward civil law comparability by saying as little about them as possible. The common law volumes include house counsel (again statistically it would often be hard to exclude them). The European volumes are ambivalent. They simply have no way of distinguishing between a "jurist" who does law jobs for his or her firm and an enterprize employed lawyers. (The Japanese report notes that a formal differentiation between the two may be developing there.)

The bottom line, of course, is that in the common law world, with various exceptions and qualifications, all those with a law degree are considered by themselves and others to be "a lawyer" while in civil law countries only some of those with law degrees are one of three kinds of lawyers. Moreover the three kinds of lawyers are not identified by themselves or others as members of the same profession. Abel fears there may be no solution to this comparison problem.

As we have already noted, Larson's contribution to volume three may provide a solution and do so precisely because Larson is practicing a somewhat different brand of sociology, probably the structural-functional kind that Abel has been soft pedalling because of the risk that it might give aid and comfort to capitalism. For Larson defines her lawyer in terms of an attribute, specialized knowledge of law, and a function, representation. In spite of denigration by Abel and Lewis, and the constant litany of practicing lawyers that law school didn't teach them anything they needed to know, it is the law degree that is the symbol of that knowledge. European judges, government lawyers and private practitioners may not iden- 
tify much with one another most of the time. Let someone without a law degree seek to enter the ranks of any of them, however, and they quickly discover that they are, after all, lawyers. And it may well be true that an American police lieutenant with a night school law degree who has never been admitted to the bar is not much of a lawyer, he is certainly more of a lawyer than I am, a law professor with no law degree at all. If both of us said "I am a lawyer" one of us would be viewed as telling the truth (although only a partial one) and the other would not.

And to the degree that the police lieutenant was viewed as telling a partial truth, it would be because "although he is a lawyer, he is not practicing law." Here Larson's specification of practice in terms of representation may be too narrow. Representation overplays the obsolescing world of the solo private practitioner. And interestingly enough, when we seek to depict more accurately the actual modern practice of law, we find a linkage back to specialized knowledge even closer than that to be found in representation. For much of modern law practice consists not of actually representing one party in adversary or potentially adversary relations with another, but in advising clients about the potential for legal liability that would arise from contemplated future actions. Thus it is not the actual skill at representation that is central to lawyering but the knowledge of law that allows accurate prediction of the legal consequences of future events. It is true that negotiating skills have become a peculiarly valuable item of sale for lawyers, but those skills are a byproduct too of legal knowledge. In many nations, including the United States, businessmen pride themselves on their own negotiating skills. In those nations where lawyers have been admitted to negotiating circles, it is not because they initially brought negotiating skills to those circles. To see things that way would be to put the cart first. Instead in those nations where negotiation was seen as fraught with dangers of law violation and legal liability, lawyers were brought into negotiations to tap their legal knowledge and then they acquired negotiating skills. In countries where cartelization and government-cartel partnership render legal risks minimal, such as Japan, lawyers are not big time negotiators. In exchange situations in which legal problems have been so reduced and routinized as to become trivial, the lawyer as small time negotiator is replaced by the real estate agent or purchasing officer. In areas where transactions were once simple but are now fraught with legal dangers, the lawyers suddenly enter where they have not been before as in the constant hovering of discrimination lawyers over corporate personnel departments. Larsons' movement to function is very useful, but the function should be seen less as a linkage between two contending parties and more as a linkage between one party and a body of knowledge which that party feels the need to tap.

If the possession and purveyance of legal knowledge is what defines the legal profession, then many of the problems of comparison fall away. The civil law "jurists" fall out because although they pos- 
sess knowledge, they do not purvey it. And the practitioners, government lawyers and judges of the civil law world can now be handled more easily as all "lawyers" together because although they are not all equally concerned with market control, they all are persons who give advice based on a particular body of expert knowledge.

Abel acknowledges in his introduction to volume three that the enterprises' initial focus "on the market rather than the state" (circa p. 81) has tended to create problems for analysis of civil law lawyers. He also argues that comparison between common law and civil lawyers may be more difficult than he initially supposed because of "the much larger roles played by judges, prosecutors, civil servants, and lawyers employed by private enterprise in the civil law world." (81) Here I think we catch Abel in a mid-course correction. The enterprise began with a clear understanding that there were three distinct civil law career paths, all of which had an equal claim to "lawyer." It saw that the common law world did not have three such distinct paths so that all common lawyers could easily be lumped together. Then because it was going to treat common law lawyers as essentially private practitioners with judges and government lawyers as just a small wriggle in the data, it was natural, in order to achieve comparability, to deal only with civil law private practitioners. The civilian government lawyers and judges could not be treated as merely a small wriggle. They must either be treated as important or left out. Given that the common lawyers with whom you wish to compare the civil lawyers are being treated as essentially private practitioners, the best thing to do is leave the civil law government lawyers and judges out. Abel now sees that too much distortion of the civil lawyers is created by leaving their government lawyers and judges out. But putting them in creates comparative problems, if you go on treating common lawyers as essentially private practitioners. For then you are comparing oranges, lemons and limes on one side with only oranges on the other. Upon further reflection, surely Abel will realize that there is a solution, namely adding lemons and limes to the common law side while acknowledging that all three of even the European varieties share the citrus qualities of knowledge and advice giving. Once we move from a concentration on market to a concentration on state and law, it may be more possible to compare American practitioners, government lawyers and judges with European practitioners, government lawyers and judges.

Abel's inclusion of "lawyers employed by private enterprise" among the non-private practitioners who play a "much larger role" in civil law countries is the final appearance of the mysterious ghost of house counsel and corporate lawyer at the feast. Here again is a sign of the learning that occurs as a large scholarly enterprise progresses. At the end we know more of what it would have been nice to know at the beginning. Legal advice does not, quite obviously, play a smaller role in common law country private enterprise than 
in civil law country private enterprise. If anything, the reverse is true. Abel's point is literally correct because in common law countries, private enterprise is likely to depend more upon retained private practice counsel than upon employed counsel. That ought not, however, obscure the importance of comparing the corporate legal advisors of common law countries with the corporate legal advisors of civil law countries. The characteristic that separates them is their contractor versus employee status. The characteristic that they hold in common, rendering legal advice to corporations, is surely as important and worthy of study once we are willing to look beyond the market control project. Once we concentrate not on employment status, but on the nature of the client served, then we may compare American and European corporate legal advisors. Interesting differences between them may or may not emerge and may or may not be linked to employee versus contractor status.

All of this suggests that there ought to be no more a conclusion to this review than there is to the volumes reviewed. This is pioneering work. One must start somewhere. Having started, new places to go are suggested. By the end of volume III the editors and the contributors who did not have to do the pioneering country by country data collection, and indeed some of those who did, are moving on from the project to something about the state, the law and the history of political institutions. That seems wise in the study of lawyers. Perhaps the most pressing item on the agenda is movement from mass to elite studies, more particularly the study of the prosperous lawyers who advise corporations and the government lawyers and judges who must try to save the rest of us from that advice. 